\title{
Strontium isotope stratigraphy of an Ediacaran-Cambrian epicontinental basin in West Gondwana
}

\author{
C. GUACANEME ${ }^{*}$, M. BABINSKi ${ }^{1}$, G. PAULA-SANTOS ${ }^{2}$, S. \\ CAETANO-Filho ${ }^{1}$, C. Bedoya-Rueda ${ }^{1}, \mathrm{M}$. \\ KUCHENBECKER ${ }^{3}$, H. REIS ${ }^{4}$, R. TRINDADE ${ }^{5}$
}

${ }^{1}$ Instituto de Geociências, Universidade de São Paulo, São Paulo 05508-080, Brazil

${ }^{2}$ Universidade de Campinas, Campinas 13083-855, Brazil

${ }^{3}$ Universidade Federal dos Vales do Jequitinhonha e Mucuri, Diamantina, 39100-000, Brazil

${ }^{4}$ Universidade Federal de Ouro Preto, Ouro Preto 35400-000, Brazil

${ }^{5}$ Instituto de Astronomia, Geofísica e Ciências Atmosféricas, Universidade de São Paulo, São Paulo 05508-090, Brazil

The Bambuí Group is exposed within the São Francisco craton (Brazil) and represents the sedimentary record of a late Ediacaran to Cambrian foreland basin system that evolved during the West Gondwana assembly. Carbonates from its basal $2^{\text {nd }}$-order sequence show an increase in $\mathrm{Sr} / \mathrm{Ca}$ ratios $(0.001$ to 0.004$)$ coupled to a progressive decrease in ${ }^{87} \mathrm{Sr} /{ }^{86} \mathrm{Sr}$ ratios $(0.7086$ to 0.7076) from lower transgressive to upper regressive strata. We argue that the high variability of both $\mathrm{Sr} / \mathrm{Ca}$ and ${ }^{87} \mathrm{Sr} /{ }^{86} \mathrm{Sr}$ ratios do not mark changes in the strontium isotope compositions of the global Ediacaran-Cambrian oceans. Instead, these variations are related to the progressive restriction of the Bambuí basin system due to the tectonic uplift of the Neoproterozoic orogenic belts at the margins of the São Francisco paleocontinent, in the core of West Gondwana. The decrease of the $\mathrm{Sr}$ isotope ratios and the concomitant enrichment in [Sr] content precedes the up to $+16 \%$ o $\delta^{13} \mathrm{C}$ positive excursion recorded in the middle Bambuí Group, which is also considered an effect of paleotectonic restriction. The isolation of the foreland basin resulted in a smaller marine $\mathrm{Sr}$ reservoir and a higher isotope variability, controlled mainly by weathering fluxes from source areas. Thus, the input of $\mathrm{Sr}$ derived from the surrounding orogens played an important role in the Sr isotope system of the Bambuí basin. Similar anomalies in the strontium budget are also recorded in coeval marine basins developed within the West Gondwana and suggest that tectonics might have played an important role on chemistry of other tectonically (?) restricted seas at the late Ediacaran and early Cambrian times. 